\title{
Increase budget revenues of various levels by economically limiting tax paying potential
}

\author{
Ahrorov Zarif \\ Independent researcher, Samarkand Institute of economics and service, Samarkand, Uzbekistan \\ * E-mail of the corresponding author akhroroff@mail.ru
}

\begin{abstract}
The article is devoted to the analysis of the economic limitation of tax potential in budget revenues. Moreover, this paper makes scrutinized investigations on the assessment of tax potential and tax paying potential. Therefore, analyses make both theoretical and practical conclusions with suitable recommendations on the growth of tax revenues in the budget system.
\end{abstract}

Keywords: tax, taxation, tax potential, tax burden, tax capacity

DOI: $10.7176 / \mathrm{EJBM} / 11-10-10$

Publication date: April $30^{\text {th }} 2019$

\section{Introduction}

In recent years, the country has been paying particular attention to tax reforms, and the tendency of radical reform of tax authorities, simplification of tax legislation and tendency of supporting business entities is constantly being implemented.

Theoretical and practical interpretation of the potential ${ }^{1}$ for tax paying and its identification is increasing. Today, hundreds of economic literatures have a comprehensive understanding of tax and tax potential. But in economic literature, which is part of such controversial issues, the tax potential is far from the essence of practice, and it can be said that it is impossible to apply it.

At present, the share of research works on the scientifically-theoretical study of tax potential of our republic, especially the region (city, district), is quite low. The lack of adequate attention to the research of opportunities for tax collection and, consequently, the lack of a uniform methodological approach to tax policy imposes a more complicated tax system. Here, we focus your attention on the definition and description of the "tax potential".

\section{Literature Review}

"The concept of "tax potential" for scientific literature was recognized by Canadian and American economists and financiers from 1980 to 1999, which is now reflected in tax practices and laws of most countries. According to the results of the research, the tax potential represents the amount of tax revenues in applying the uniform taxation system. But it does not mean that its content is still abstract.

Gorskiy I.V. "Tax potential is an abstract financial category that represents an optimal amount of tax imposition (optimal tax burden) for a particular subject of the tax system" [1]. Of course, all these tax reforms are based on the steady growth of state budget revenues and the implementation of the innovative potential of taxpayers. However, this interpretation of tax potential seems to be out of the reach of scientists. Therefore, the concept of 'tax potential' The interpretation given by Gorsky indicates that some of the possibilities are ignored.

Lyatina E.V. "Tax potential is a system of calculations that can be characterized by a fiscal policy in the context of taxation of sources and objects that give a qualitative character of the state of the country or region and existing and interact within the economic framework" [2]. Mayburov I.A. considering the tax potential as a potential ability to maximize the tax revenue of the budget at all levels with financial resources in the context of current legislation and tax administration, taking into account the actions of taxpayers [3].

In scientific literature, there are several versions of the concept of taxpayers, with the exception of the above. Also, the authors differ in their ability to compare the tax potential with budget revenue potential or potential taxpayer potential. For example, Panskov V.G. Taxpayers are the maximum possible tax deductions in a given region at certain times under current taxation law [4].

Polinskaya M.V. tax potential is the maximum amount of tax that can be collected from the territory without violating the economic potential of the region, where Yutkina T.F. tax potential - is a sum of total cash earnings 
from all goods, works and services manufacturers aimed at reducing production and treatment costs [6].

It should be noted that the tax potential can not be compared to the sum of producers and other money earnings.

It is incorrect to estimate the tax potential of the region as a whole, because there is a difference between the actual tax rates and the potential for generating budget revenues. Taxes collected by taxpayers in regions may differ, as the tax base can be affected by the factors such as the effectiveness of tax authorities and the tax compliance discipline of taxpayers [7].

Timely L. Alfirman stochastic boundaries attempted to clarify the concept of "tax burden" by trying to distinguish the prognosis of tax revenues as a result of a regression analysis, and suggested separately the "tax potential" and "tax burden". However, this concept is also expressed by the concept of financial resources [8].

From the above, one can say that tax potential is one of the most important aspects of taxpayer taxation, and in tax literature, the concept of taxpayers is used in the same way as the budgetary tax revenues.

It is a collection of monetary resources accumulated on the basis of ideas and research designed to exploit a wide range of tax potential, the level of development of the system, the quality and quantity of tax revenue, the practical use of those opportunities. In the process of compulsory monetary payments, there is a legal act of collecting and centralized collection of tax proceeds.

As a result, the tax is based on the scientific potential of the majority of academic economists focused on the implementation of the laws on the basis of a set of centralized monetary resources to try to evaluate.

\section{Object of subjects}

Territorial tax potential (lat. potential) is the sum of taxes, taxable payments, as well as the sum of additional tax payments, calculated as a result of control over the tax and customs authorities, in the context of the tax legislation, ie actual actual taxes and the ability to collect budget revenues [9].

The tax potential is characterized by the economic structure and the availability of taxable resources, which are determined by the tax base and affects the formation of local budgets' revenues.

The tax potential exists in the premises of economic relations and reflects the size, structure and distribution of financial resources. Taxpayer identification is crucial in determining the projected indices, and it serves as an important tool for the interregional governance of the regions, depending on the potential of the region, subventions and loan distribution mechanisms can be formulated [10].

Economist scientist prof. J.R. Zaynalov also pointed to the concept of "tax potential" in his scientific works. [11] But in his scientific views, he managed to substantiate the economic potential of tax potential from the theoretical and practical point of view. Indeed, it is no secret that any size can be a limit. It's worth mentioning, J.R. Zaynalov estimates the term taxpayer as a 'tax frontier', where there is a quantitative distinction between the term 'tax potential (TP) or "tax margin" (TM) there are quantitative differences between the terms. $\mathrm{TM} \geq \mathrm{TP}$ or TM $<\mathrm{TP}$ the tax burden reflects the tax burden on GDP, and the taxpayer's inclusion of non-taxable earnings. In the same way, we may face a similar situation. Therefore, the taxpayer is more than the limit, which can be reflected in the competitiveness of the enterprises, budget revenues, the rise in inflation levels, and the declining population's solvency. Therefore, it is important to emphasize that the emphasis on "taxpayer potential" instead of "tax potential" is theoretically and practical.

"Taxpayer Potential" occurs at the stage of formation of tax payments. Changes in the tax base under certain micro and macro indicators will change the tax burden. As a result, taxpayer potential is formed. If we consider taxpayers, then it will set their predetermined boundaries at the predictable limits by limiting taxation and avoiding factors affecting taxation. But it is impossible to implement it. This concept clearly explains that direct taxes are levied and restricted within the limits of the law.

It is the taxation that has its own borders that stimulates taxpayers and creates the basis for the recognition of taxes as an economic reality that generates profits. According to prof. J.R. Zaynalov, every payment, every kind of payment, every penalty (even if it is a negative) should generate income (benefits) to an economic entity and increase its financial potential for economic growth [12] .

\section{Data analyses}

While recognizing such an idea, we consider it important to make a profit (profit) from the unforeseen costs involved in the aforementioned economic realities and to point out that it is a taxable object. These losses 
can reduce the tax burden. It is also desirable to consider these losses as "potential taxpayers", not as a "taxpayer potential", but as a result of any risk resulting from such a situation.

Unfortunately, these kinds of interpretations are still being widely accepted by most economists [13] [14] [15] [16] [17]. In our opinion, the meaning of these concepts is closely related, but not exactly the same. It would be better to interpret the financial resources of the provincial (city or district) as part of the existing taxpayer potential, in other words, cash generated through the use of available resources.

The taxpayer potential of the republic should be interpreted as "the potential of existing resources on the ground to generate income to economic entities" for a certain period of time. In fact, the existing financial resources available in our country may not be used for any reason. Therefore, if the financial opportunity appears as an assumption of consciousness, then we would have to look at the possibility of taxpayer probability. The dynamic change of financial resources in a broader sense has a negative impact on the tax burden, the clear benefits of tax benefits that can be applied to taxes and even taxes. This also affects the formation of different levels of budget revenues (Graph 1).

Graph 1. The module of losses, which can be used when applying concepts that have a role in formulating budget potential

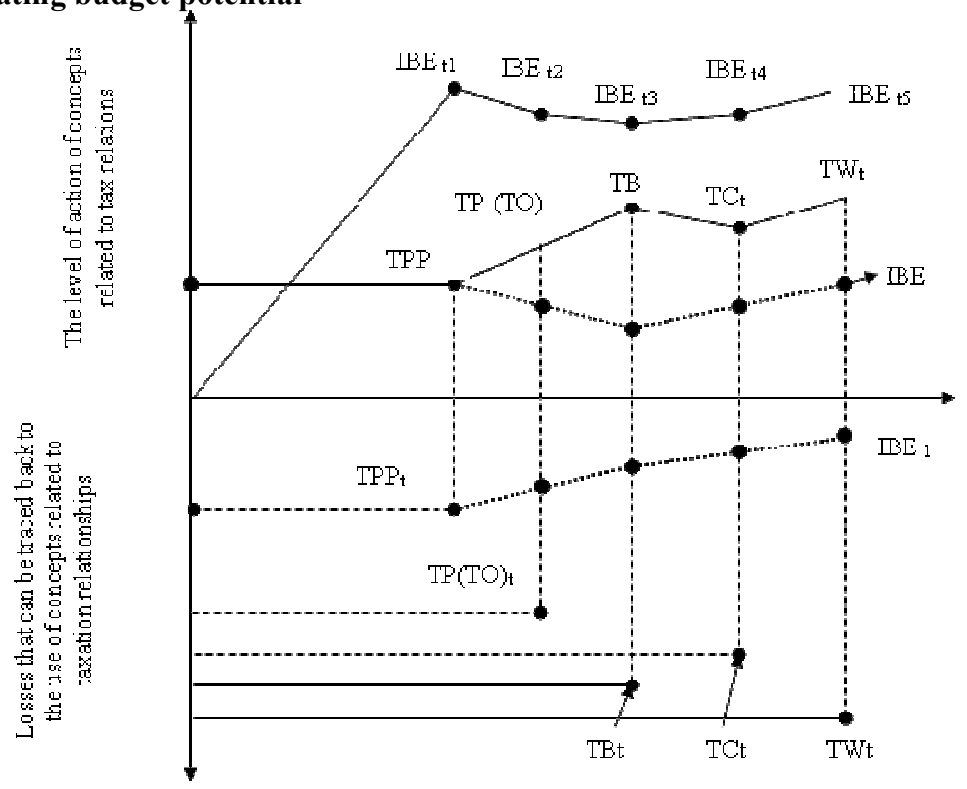

Here: TPP - taxpayer potential; TP(TO) - tax potential (tax opportunity); TB - tax burden; TC - tax capacity; TW - tax weight; $\mathrm{t}$ - losses that can be observed during the specified period (time); IBE - an increase in the business economy; $t_{1,2,3}$ - additional features that can be observed during the specified period (time).

Graph 1. The module of losses, which can be used when applying concepts that have a role in formulating budget potential

As can be seen in Graph 1, the potential for strengthening and improving the budget potential by applying terms that promote tax relations.

It is important to note that the TPP - the concept of application and application of the concept creates a reliable foundation in all respects. So, in terms of creating opportunities TPP > TP(TO); TPP > TB; TPP > TC; TPP $>$ TW

(1)

here: $\mathrm{TB}>\mathrm{TC} ; \mathrm{TB} \geq \mathrm{TW}$

$\mathrm{TP}(\mathrm{TO})>\mathrm{TB} ; \mathrm{TP}(\mathrm{TO})>\mathrm{TC} ; \mathrm{TP}(\mathrm{TO})>\mathrm{TW}$

TC $>$ TB; TC $<$ TPP; TC $<$ TP(TO); TC $>$ TW 
Even if any achievements are not within the scope of the terms used, there are also expected losses. But, as set out in Graph 1, it is the least loss TPP is observed. This loss can be traced primarily to the fact that the elements of the taxation mechanism are not optimally aligned or that various legal restrictions apply to tax payments. In the rest TP (TO), TB, TC, TW it is natural that these factors are also affected. However, the exercise of these terms can be overlooked or overlooked. Moreover, the tendency for growth of such negative phenomena will increase even if there is a discrepancy between the various laws. It can also dramatically change the action of companies in the area where they can be used $K$ and $K_{1}$ - the movement of enterprises).

According to the analysis, when analyzing the structure of financial resources, it is possible to observe the financial resources of the economic entities of the republic, and recently the population. Therefore, when identifying some taxpayers, there are attempts to distinguish between the financial capacity of the subjects and the population. In our opinion, such a description is shallow.

"Taxpayer potential" is, in many ways, a reference to situations that are typical for the state, a separate local government (local budgets). At the same time, it is worth noting that in some ways it is possible to speak about the taxpayer's ability to operate, but it is very difficult to assess the taxpayer potential of the population.

Within the framework of the local governance system, evaluation requires a unique approach. Unfortunately, the Ministry of Finance of the Republic of Uzbekistan, the State Tax Committee and the scientific centers under the Ministry of Economy have not developed concrete recommendations and guidelines on taxation and budgeting. This has further aggravated the problems of taxation.

In addition to the above points, we can say that the concept of "tax paying capacity" is the basic concept characterizing the financial potential of the region (city, district). From this perspective, economists have different views on the meaning of this concept. A group of them - "taxes - total liabilities to taxpayers", while the other group - the total amount of tax payments, which should be accumulated in the budgetary legislation in the proper order during the fiscal year, as well as the level of tax revenues to be achieved based on the future development prospects of the taxation Republic they say. As you can see, the interpretations are varied. But they have a common feature. It's a matter of raising taxes on taxpayers on the basis of all interpretations. However, these views are unilateral and limited to the scope of the authors' research.

In particular, regardless of the extent to which these names are mentioned, their economical essence as a precise term is not explicitly disclosed by economists. We have come to explain the concept of "tax potential" as follows. "Taxpayer potential is the economic reality describing the sum of tax relations legally emerged between the state, enterprises and citizens linked to the formation of budget revenues at different levels reflecting the real frontiers of tax collections and payments.

The reforms carried out in the tax system of the country are important in studying the international experience in promoting economic development. Nowadays, tax reforms in the US are not comparable to the tax reforms in the United States in the 1970s, but their proximity to taxes and economic growth is crucial. For example, the increase in tax revenues by reducing the tax burden over corporates and reducing the budget revenues from 14 to 12 per cent, the lowering of the individual income tax from 50 to 28 per cent ( 70 per cent of the highest revenues at that time) and the interests of corporations and financial oligarchy [18].

It should be noted that introduction of tax deductions in the USA also yielded results. This discount came in the name of a tax credit. These activities have provided subsidies for corporations over the long term. It is recognized that this tax credit is based on $10 \%$ of the company's capital investment, or that it has a profit tax rate of $20 \%$, which ensures economic growth [19].

Measures taken in line with tax reforms also played a crucial role in reducing the accelerated depreciation charges for some corporations.

It is worth noting that in the US, earnings are about $\$ 1$ million. In 1964, tax rates were set at 20-91\% in $1964,70 \%$ in $1965,60 \%$ in $1971,50 \%$ in 1972 , and later at the end of the 20 th century at $35-50 \%$. However, a tax that is not taxed is set at a minimum of $\$ 6,000[20]$.

In fact, there is a need to consider taxpayer payments in Uzbekistan based on best practices. At the same time, special attention should be paid to determining the taxpayers' need for financial resources, their accumulation and target orientation. This, in turn, implies the need to upgrade the earnings that can be deducted from taxation, and to improve the mechanisms for evaluating the objective conditions for it.

The solution of this issue is directly related to the increase of the order of forecasting the sources of income generation in our country. 
Formation of the local budget and the substantial determination of the level of financial support by the high budget segment depend on the objective assessment of the revenue potential of local budgets. Nowadays there is a need to develop a procedure for long-term forecasting of the local budget's revenues and to raise the source of their incomes from the scientifically-practical needs. Nowadays, the issue should be ignored. An important factor in finding a quick solution is to increase the local government's interest in raising local budgets. It is important to evaluate the tax burden of the province (city, district) as it is important to select the most optimal assessment methods.

It should be noted that, as a result of studying the work of local and foreign economists, local budgets do not have the potential to assess the tax burden. Available methods are classified according to the types of tax payments, macroeconomic indicators, and methods of representative taxation.

\section{Conclusion}

At present, there are a number of shortcomings in the system of tax planning of tax revenues, ie the lack of a regulatory framework regulating the activities of responsible agencies and their subdivisions dealing with forecasting and formulating tax tasks; The lack of interest from local self-governance bodies in the development of tax opportunities; it is noted that there is a widespread practice of tax collection in practice, which means that some enterprises (organizations) will have to increase tax payments (and even mandatory payments) for future periods to carry out the forecasted tax earnings.

In order to analyze the importance and significance of taxes on budget revenues, it is important to study the importance of tax revenues at every stage of the budgetary reforms.

Thus, it is important to ensure that the radical reforms implemented in the tax system are focused on increasing the financial capacity of legal entities and individuals, depending on the circumstances. This, in turn, can have an impact on the country's economic potential. Increasing the economic potential of the country can lead to the increase in their taxpayer potential.

In fact, the change in the taxpayer potential is inextricably linked with changes in the taxation system. In the current situation, the only way to increase the tax burden on the budget is to make continuous reforms in the country's tax system to increase taxpayer potential.

\section{References}

1. Gorsky I.V. Tax potential in the mechanism of intergovernmental relations // Finance. 1999. № 6.

2. Lyatina E.V. Formation and assessment of the tax potential in Russia: author. dis. on the competition scholarly step. Cand. economy Sciences - URL: www.seun.ru/download/ avtoreferat / lyatina.doc - p.6

3. Maiburov, I.A. Tax management. Advanced course [Electronic resource]: a textbook for undergraduates enrolled in the programs of the direction "Finance and credit" / I.A. Maiburov [et al.]. - Electron. text data. - M .:, 2014. - 559 page.

4. Panskov V. G., Knyazev V. G. Taxes and taxation. - M .: MCFER, 2003. - p. 576.

5. Polinskaya M.V. Tax potential: discussion approaches to the definition and methods of assessment / M.V. Polinskaya, V.S. Zachishigriva // Polythematic network electronic scientific journal of the Kuban State Agrarian University. - 2017. - №133. - p. 861-871.

6. Yutkina, T. F. Taxes and taxation: a textbook. - M .: INFRA, 1999.

7. Pelevin I.Yu. Analysis of conceptual approaches and methods for assessing the tax potential of regions. Statistics and Economics. 2014; (5): 70-72. https://doi.org/10.21686/2500-3925-2014-5-70-72

8. Alfirman, L. Estimating stochastic frontier tax potential: Can Indonesian local governments increase tax revenues under decentralization / L. Alfirman //Department of Economics, University of Colorado at Boulder, Colorado. Working Paper. - 2003. - №. 03-19.- 37 p.

9. Mirzaev F. Methods and practice of calculating tax collections. // Business-Expert. 2012. http://www.biznesdaily.uz/ru/birjaexpert/15687-soliq-yigiluvchanligini-hisoblashning-uslubiyoti-va-amaliyoti

10. Khudoykulov S.K. Improving the methodology of tax assessment of the regions. Increase tax collection and other compulsory payments by improving tax administration. Republican scientifically-practical conference of 
theses. Tax Academy, Tashkent, 2018, page 358.

11. Zaynalov J.R. Taxes and taxation. Educational manual. - Samarkand, Samarkand Cooperative Institute , 2002. - 365 page.

12. Zaynalov J.R. The need to ensure mutual fiscal and tax policies in a favorable state of economic and legal atmosphere. / Global problems of modernization of the national economy. Proceedings of the VI International Scientific and Practical Conference (part-time): in 2 parts. Tambov, April 26-28, 2017

13. Malikov T. Need to reduce the weight of the tax burden sharply?

- T.: National Library of Uzbekistan named after A.Navoi, 2006. 32-p.

14. Turaev Sh. Issues of optimization of tax burden on business entities. Candidate of economic sciences. For the degree of Doctor of Science - T .: 2007. 88-89 p.

15. Shirinov S., Kodirov R. Some issues of improving tax burden calculation methodology. // Finance. \# 1. 2016 48-51 page.

16. Sanakulova B., Badalov Sh. Tax burden: directions of identification and optimization. Monographs. T .: 2015. - 264 page.

17. Adizov S.R. Modeling and forecasting of tax burden on macroeconomic indicators. Doctor of Philosophy in Economics (PhD) diss. avt - T .: 2018, etc.)

18. https://ru.wikipedia.org/wiki/Рейганомика (recieved: 17.02.2019).

19. Ermakova E.A., Larionov N.A. Tax credits in the system of stimulating innovation activity // Manager. 2015. №2 (54). URL: https://cyberleninka.ru/article/n/nalogovye-kredity-v-sisteme-stimulirovaniya-innovatsionnoyaktivnosti (recieved: 17.02.2019).

20. Sabanty B.M. Theory of Finance. Educational material. 2nd ed. - M .: Manager, 2000. - p. 154-156. 